\title{
Exploratory Evaluation of Retranslocation and Bioconcentration of Heavy Metals in Three Species of Mangrove at Las Cucharillas Marsh, Puerto Rico
}

\author{
Mejías $\mathrm{CL}^{1 *}$, Musa JC ${ }^{1}$, Otero $\mathrm{J}^{2}$ \\ ${ }^{1}$ School of Environmental Affairs Universidad Metropolitana, San Juan, Puerto Rico \\ ${ }^{2}$ School of Management, Universidad Metropolitana, San Juan, Puerto Rico.
}

\begin{abstract}
Heavy metal contamination in the coastal area of Cataño, Puerto Rico accountable to anthropogenic sources is of great concern due to the risk posed over the surrounding communities and adjacent ecosystems. Estuarine ecosystems are widely recognized for the presence of mangroves. This type of flora is recognized for their many beneficial properties for example, the ability to purge aquatic ecosystems where they stand. Exploratory analyses on the phytoaccumulative capacity of three mangrove species for ten metals $(\mathrm{Hg}, \mathrm{Al}, \mathrm{As}, \mathrm{Cd}, \mathrm{Cr}, \mathrm{Cu}, \mathrm{Fe}, \mathrm{Pb}, \mathrm{Mg}, \mathrm{Zn})$ were performed in this research. Random soil samples and both green and senescent leaves of Rhizophora mangle, Laguncularia racemosa and Avicennia germinans from three different sites of Peninsula La Esperanza were analyzed in order to apply the retranslocation efficiency (RT\%) and bioconcentration factor (BCF) concepts. After calculating the $\mathrm{RT} \%$ and the $\mathrm{BCF}$, comparison analyses among the three mangrove species were performed. In general, the results showed low RT\% values for Avicennia in comparison with Rhizophora and Laguncularia. BCF values confirmed RT\% results for Avicennia, showing higher heavy metal concentrations in its senescent leaves in contrast with the other species. Therefore, these preliminary results suggest that Rhizophora and Laguncularia act better as phytoremediators for heavy metals in polluted areas due to their ability to accumulate lower concentrations in senescent leaves; preventing further contamination in surrounding ecosystems by encapsulating the pollutants instead of exporting them.
\end{abstract}

Keywords: Bioremediation, Phytoremediation, Phytoaccumulation, Retranslocation, Bioconcentration

\section{BACKGROUND}

The study site is an integral component of the San Juan Bay Estuary system (SJBE). The SJBE was designated by the US Environmental Protection Agency (USEPA) as a resource of national importance in recognition of its economic, environmental, and recreational importance and, moreover, to the continued threats facing this estuary. Thus, the SJBE was integrated in 1992 to the U.S. Environmental Protection Agency's (USEPA) National Estuary Program (NEP). The mission of the NEP is to protect and restore the health of estuaries while supporting economic and recreational activities [1].

The SJBE is located in the northeast coast of the island of Puerto Rico (Figure 1) and is

Corresponding Address:

Carla Lorraine Mejías-Rivera

Tel. 787-617-9750

E-mail: cmejiasrivera@yahoo.com composed of a system of water bodies and highly complex and interconnected wetlands which pass through eight of the most populated municipalities of the island. Among these wetlands there is Las Cucharillas Marsh. The highly diverse ecosystem existent at Las Cucharillas plays a very important role for a great variety of flora and fauna species, some of them even endangered. This wetland helps control the floods in the area and improves water quality. Unfortunately, due to the high population and industrialization surrounding the marsh, large level of contaminants, specifically heavy metals, have been affecting this ecosystem $[2,3]$.

It is of general knowledge that urban and industrial activities significantly increase the heavy metal concentrations in the water and sediments surrounding the source facilities $[4,5]$. Elevated concentrations of trace metals pose a perennial threat to ecosystems due to their inability to be degraded biologically [6]. Lacerda et al. (1993) and Machado et al. (2004) [7, 8] 
described how trace metals accumulate on mangrove fine roots also known as rhizospheres. While, Wen-jiao et al. (1997) [9], assessed the accumulation of 7 heavy metals in different parts of Rhizophora stylosa. All of these results confirm the ability of mangrove species to accumulate trace metals in different parts of the plant although it seems to depend greatly on the specific type of mangrove species and on the physicochemical characteristics of the sediments.

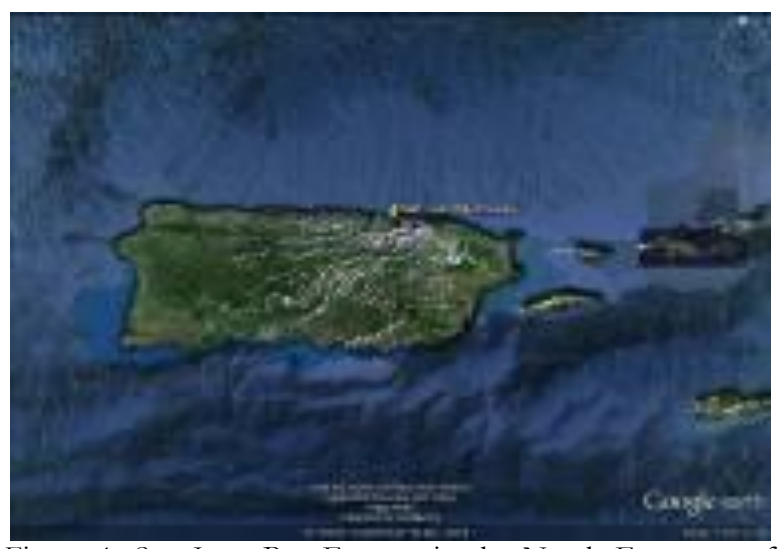

Figure 1. San Juan Bay Estuary in the North East part of the Island of Puerto Rico

With the aim of trying to control the constant growth of contamination new technologies have been developed. Technologies that favor the natural processes are mostly preferred; for example bioremediation. Bioremediation, is the use of living organisms that aid in removing pollution [10]. A related bioremediation technology is phytoremediation; which is the process of using plants to extract, sequester and/or detoxify pollutants [11]. Since we are dealing with heavy metal contamination it is important to note that heavy metals are not degraded, therefore, in this case, the only possible processes are the extraction of the pollutants from soil and their sequestering (accumulation) into plant tissues. Translocation, or movement of heavy metals from the roots to aerial parts of the plant, may also occur [12]. Depending on physicochemical characteristics of soil, after the extraction of heavy metals from said matrix further accumulation in plant tissues, bioconcentration, may occur. There are two processes that this research aims to evaluate; retranslocation (RT\%), or movement from senescent leaves back to the plant, and bioconcentration (BCF) of heavy metals in mangrove leaves in relation with soil concentrations. As per our knowledge no studies on the retranslocation of heavy metals on mangrove leaves have been done in Puerto Rico. However, the retranslocation or nutrient use efficiency on plants has been widely studied [13, $14,15,16,17]$.

In our research area, mangrove species Rhirophora mangle, Laguncularia racemosa, and Avicennia germinans are abundant. These three species have been widely recognized for their ability to extract and accumulate heavy metals in root/sediment interface and different parts of the plant, including but not limited to roots, stem and leaves, $[6,7,9,8,18,19,20,21]$. Mangroves all around the world play a very important role due to their ability to stabilize coastal lands and provide safe and propitious environment for the development of diverse ecosystems. They serve as feeding, breeding and nursing environments for a variety of wildlife [4].

Due to the location of our research area and the existent contamination problems, this research project intends to assess the heavy metal contamination at Las Cucharillas Marsh. Our purpose is to understand the mechanisms by which Laguncularia racemosa, Rhizophora mangle and Avicennia germinans interact with heavy metals calculating the $\mathrm{RT} \%$ and the $\mathrm{BCF}$.

\section{MATERIALS AND METHODS}

\section{Description of the Study Area}

Las Cucharillas Marsh has an extension of approximately 1,236 acres, which are composed primarily of herbaceous wetlands, mangroves and open water areas. This wetland receives industrial runoff from several industrial parks and raw sewage discharges form surrounding communities (ie. Juana Matos, Puente Blanco). A mitigation site of about (12 acres), identified as Universidad Metropolitana (UMET) research area, is located one mile from our research location. This research area is divided into two mitigation zones known as Bacardi and Flexitank. A creek running through three surrounding municipalities, La Malaria Creek, receives and finally discharges raw sewage waters and industrial runoff at our site of investigation. All these components may be contributing to the contamination at our research site.

Our research site at Las Cucharillas marsh is specifically located at the following coordinates, $18^{\circ} 27^{\prime} 06.28^{\prime \prime} \mathrm{N}$ and $66^{\circ} 08^{\prime} 07.09^{\prime \prime} \mathrm{W}$ (Figure 2). Coordinates were calculated using Garmin $72 \mathrm{H}$ GPS technology and based on the North American Datum of 1983. This place also 
known as La Esperanza Peninsula, located in the northwestern section of the San Juan Bay, is composed of two man-made islands created by the placement of dredged material from the dredging of the San Juan Bay navigational channels during the sixties [1]. For purposes of this study, this area was divided into three subareas (A, B, C) (Figure 3). Zone A $\left(18^{\circ} 26^{\prime} .980^{\prime \prime} \mathrm{N}, 66^{\circ} 08^{\prime} .203^{\prime \prime} \mathrm{W}\right)$ being a mostly urbanized area, Zone B $\left(18^{\circ} 27^{\prime} .270^{\prime \prime} \mathrm{N}\right.$, $\left.66^{\circ} 08^{\prime} .032^{\prime \prime} \mathrm{W}\right)$ known as Park La Esperanza and

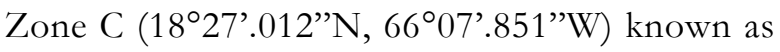
La Esperanza Isle. Each of these zones has specific characteristics that can affect heavy metal availability. Zone A is directly affected by water currents coming from the bay and by the effluent of La Malaria Creek. Park La Esperanza, Zone $\mathrm{B}$, is the most protected site because it is situated in the leeward side of the peninsula, protected from the prevailing NE winds (Trade Winds) and currents. Zone $\mathrm{C}$ is an isle that encloses the whole site. Back in 2003, the US Corps of Engineers decided to dredge the sediments from the "berm" with the aim of opening water access to the lagoon. The sediments dredged were deposited in the center part of Zone C.

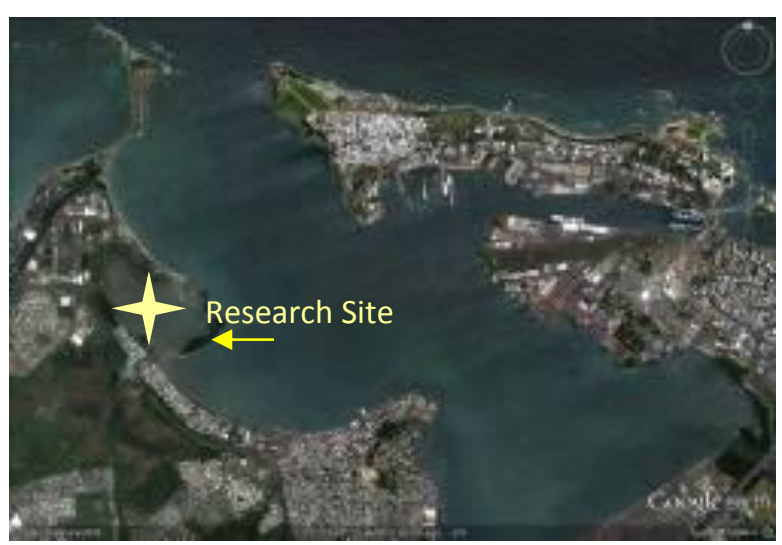

Figure 2. San Juan Bay and Research Site

\section{Sampling and Analysis \\ Sediments}

A total of three composite sediment samples were taken at random at each zone, following Environmental Protection Agency (EPA) [22] sediment sampling standard methods (SOP\# 2016). Samples were handled using a stainless steel spatula to a depth of five inches (discarding the first inch). Samples were stored in closed sterile 6oz. glass containers $(\sim 170 \mathrm{~g})$ and refrigerated until taken to a certified private lab for analysis.

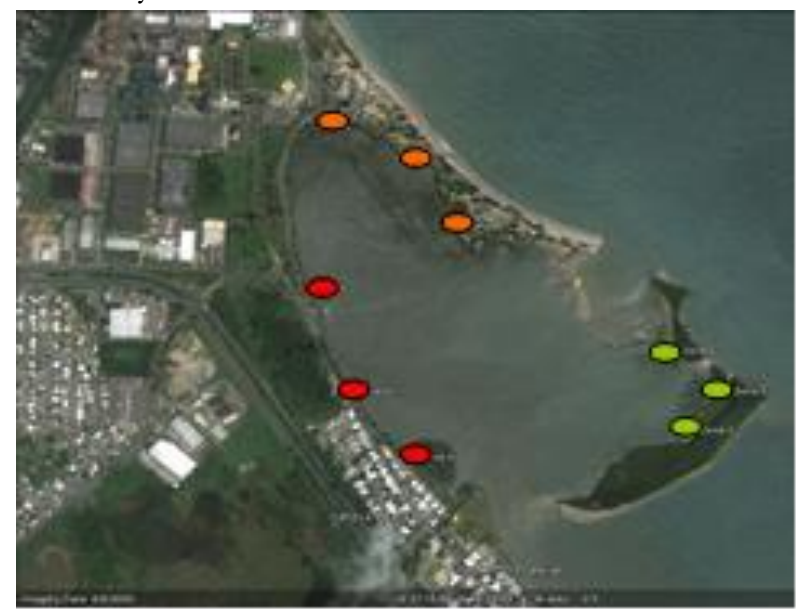

Figure 3. Research site subdivision: Zones A (Red); $\mathrm{B}$ (Orange); C(Green).

\section{Leaves}

Approximate 50 leaves per each species were collected ( 25 green and 25 senescent) in each of the three selected zones. The leaves selected were the ones least fed upon by insects and looked more intact. Green leaves were specifically picked from the first and second lateral branch [9]. Leaves were stored in labeled plastic bags. Labeling included 1) mangrove species, 2) zone and 3) state (green or senescent). Samples were refrigerated until they were taken to SANCO, a private environmental laboratory, for analyses.

\section{Heavy metal analysis}

Both, sediment and leaf samples were analyzed using Induced Coupled Plasma (ICP) instrumentation, following EPA's method 6010C for most of the heavy metals and 7471B specifically for Mercury ("Standardized Analytical Methods for Environmental Restoration Following Homeland Security Events") [23]. Based on our sediment analysis results, heavy metals for further analysis in leaves were selected. The selection was made taking in consideration toxicity and concentration in the area when compared to Florida's Baseline [24].

\section{Determination of $R T \%$ and $B C F$}

The RT\%, or movement from senescent leaves back to the plant, for each metal in each of the species was calculated using Allison and Vitousek 
(2004) [16] Lugo's (1998) [13] formula (Equation 1). The results of these calculations were compared among species to determine which mangrove species retranslocates the greatest amount of heavy metals.

$$
\% R T=\left(1-\frac{[\text { HMsenescent }]}{[\text { HMgreen }]}\right) * 100 \quad \text { Eq. } 1
$$

The BCF, or accumulation of heavy metals in mangrove leaves in relation with soil concentrations, for green and senescent leaves was calculated respectively as described in Mellem et al.'s (2009) [12] formula. The resulting data were used to compare the levels of heavy metals accumulated in leaf tissue in respect with the original concentration in soils.

$$
B C F=\frac{[\text { HMLeaves }]}{[\text { HMSoil }]}
$$

\section{Statistical Analysis}

Statistically significant differences between mangroves species were assessed using one way analysis of variance (ANOVA) and T-test multiple comparison in Statistical Package for the Social Sciences (SPSS) version 18. ANOVA was specifically employed to assess the significance between green and senescent leaves among the species and zones. In the other hand, T-test was used to assess significance in leaves among the three species after $\mathrm{RT} \%$ and BCF calculations.

\section{RESULT AND DISCUSSION}

\section{Sediments}

Due to the lack of federal regulations over the concentration of heavy metals in sediments it is necessary to acquire baseline concentrations specific to the site desired to be studied [24]. Kabata-Pendias et al (1992) [25] expressed that natural background concentrations of trace elements can be used as reference values for each specific site, but it needs to have no human influence. In our site, it is very difficult to meet with this specification due to the heavy industrialization and dense population surrounding the area. Therefore, based on the similarity of the soil composition we used Chen et al (1999) [24] data from Florida soils to compare with our results.
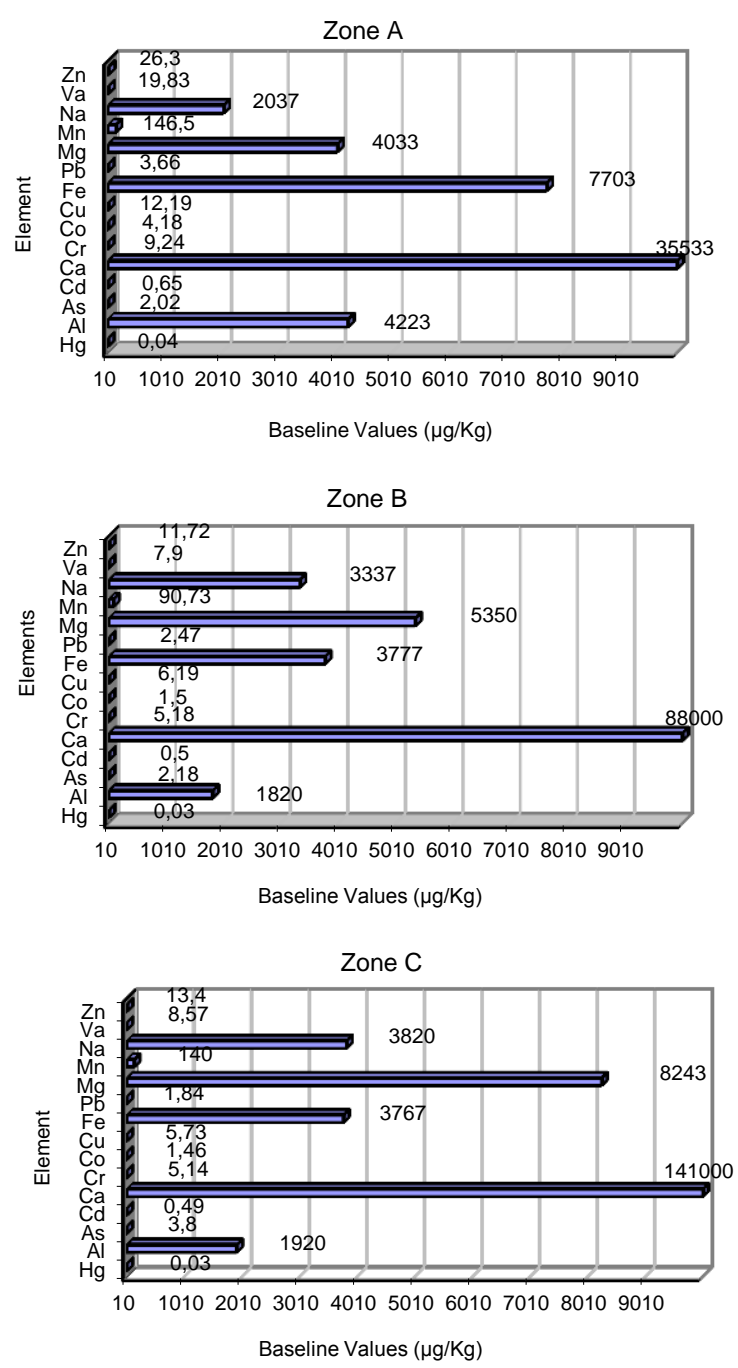

Figure 4 . Soil analysis results by zone

Previous soil [3, other UMET unpublished reports] data from UMET research area, Juana Matos, Puente Blanco, Malaria Creek and Bayamón river showed high concentrations of heavy metals compared to Floridas' baseline [24]. Sediments of Malaria Creek and Bayamón river concentrations of As were higher (12.2 and 9.85 $\mu \mathrm{g} / \mathrm{Kg}$, respectively) than baseline (0.02-7.01 $\mu \mathrm{g} / \mathrm{Kg})$. Pb concentration at UMET research area was higher $(77.6 \mu \mathrm{g} / \mathrm{Kg})$ than baseline $(42.0$ $\mu g / \mathrm{Kg})$. At UMET research area, Puente Blanco, Juana Matos and Malaria Creek the concentration of $\mathrm{Hg}$ was higher $(0.05,0.12,0.7$ and $0.13 \mu \mathrm{g} / \mathrm{Kg}$ respectively) than the upper limit of baseline $(0.04 \mu \mathrm{g} / \mathrm{Kg})$. In the same areas, concentrations for $\mathrm{Cu}$ were higher $(29.3,27.7,58.96,89.17$, and $42.3 \mu \mathrm{g} / \mathrm{Kg}$ respectively) than the upper limit of 
baseline $(21.9 \mu \mathrm{g} / \mathrm{Kg})$. Zn concentrations (36.7, $40.9,144.2,270.6$, and $117.3 \mu \mathrm{g} / \mathrm{Kg}$ respectively) were higher than upper limit of baseline (29.6 $\mu \mathrm{g} / \mathrm{Kg}$ ) also at the same areas.

Out of the 15 essential and non-essential metals identified in our research area (Figure 4), the metals $\mathrm{Fe}, \mathrm{Mg}$ and $\mathrm{Al}$ showed the highest mean values $(5031.75,6439$, and $2570.75 \mu \mathrm{g} / \mathrm{Kg}$ respectively) for the three assessed zones. These three metals in addition to $\mathrm{Hg}, \mathrm{As}, \mathrm{Cd}, \mathrm{Cr}, \mathrm{Cu}$, $\mathrm{Pb}, \mathrm{Zn}$, were selected for the assessment of retranslocation and bioconcentration on mangrove leaves due to their toxicity and relatively high concentration. Out of the three zones, heavy metal concentrations on zone A were the highest. In zone A soil analysis showed that $\mathrm{Se}$ and $\mathrm{Hg}$ have parallel concentrations to upper limit of Florida's baseline $<1.45$ and 0.04 $\mu \mathrm{g} / \mathrm{Kg}$ respectively. For the three zones, Cd showed higher values $(0.6,0.50,0.48 \mu \mathrm{g} / \mathrm{Kg})$ in comparison to the upper limit of Florida's baseline $(0.33 \mu \mathrm{g} / \mathrm{Kg})$.

Natural or geochemical baseline concentrations of heavy metals in soil will vary and depend mostly on type and physico-chemical characteristics of soil [26]. Higher than natural heavy metal concentrations in soil represent ecological risk to the entire ecosystem and its components. Maisto et al. (2011) [27] evaluated the $\mathrm{Cr}$ and $\mathrm{Pb}$ in soils by ecotoxicological tests and concluded that soils with high heavy metal concentrations have ecological risks and soils with low metal concentrations could have toxic effect due to metal availability which is related with physicochemical characteristics of soils. Due to said characteristics heavy metals such as $\mathrm{Pb}$ and $\mathrm{Cd}$ can be found bound to $\mathrm{Fe}-\mathrm{Mn}$ oxides [21] and restrain their availability for uptake. The uptake of heavy metals by mangroves can be translated into low productivity [28].

\section{Retranslocation}

In the ecophysiological process of the three species of mangrove in Las Cucharillas Marsh, the retranslocation of nutrients from senescing leaves allows the nutrients to be available for the formation of new structures $[14,28]$. Previous work carried out by Musa (1986)[29] suggests that R.mangle is more efficient in the retranslocation of $\mathrm{Ca}$ and A.germinans is more efficient in the use of N, P and K. Similar results were obtained in mangrove forests at Brazil [18]. These results, even though are for nutrients, are consistent with the results obtained in this study for heavy metals, specifically for R.mangle. Most retranslocation's results for the three species in all the zones showed low or none $\mathrm{RT} \%$ (Figure 5). The lowest RT\%'s obtained were for $\mathrm{Hg}, \mathrm{Al}$, $\mathrm{Cu}, \mathrm{Fe}$ and $\mathrm{Mg}$ from A.germinans. When comparing the three species, the $\mathrm{RT} \%$ increased in the following order A.germinans $<$ L.racemosa $<$ R.mangle.

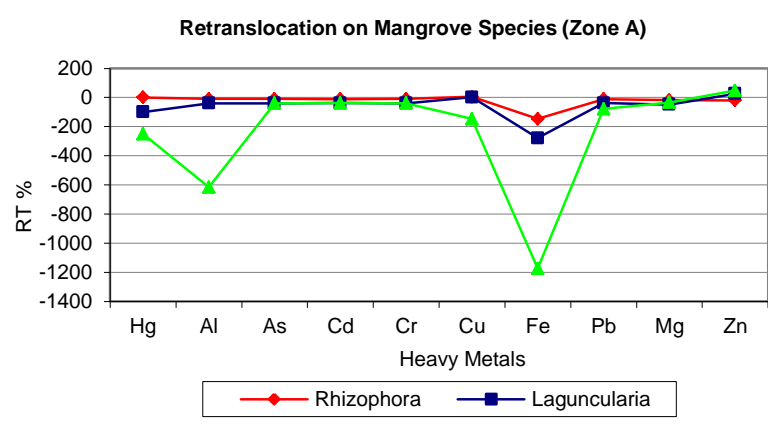

Retranslocation on Mangrove Species (Zone B)

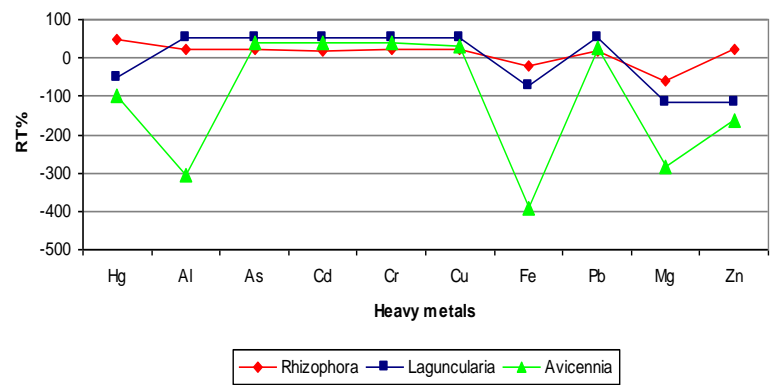

Retranslocation on Mangrove Species (Zone C)

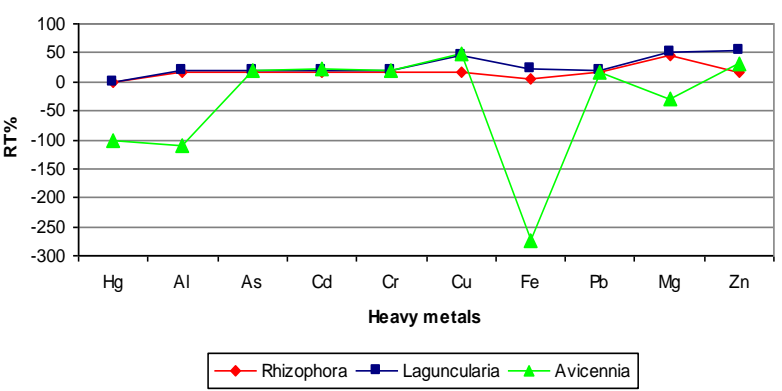

Figure 5. Comparison of retranslocation percentages among mangrove species.

These results may be due to exclusion mechanisms developed by mangroves. Exclusion mechanisms will prevent high amounts of heavy metals to intrude into plant uptake. Mac Farlane (2002) [30] analyzed the role of mangrove as excluder species for non-essential metals and regulator for essential metals. He obtained values of RT for essential metals such as $\mathrm{Cu}(0.52), \mathrm{Zn}$ (0.53) and for non-essential metal such as $\mathrm{Pb}$ (0.31). An example widely studied of these mechanisms is "iron plaques". At present, some researchers consider that the presence of iron 
plaques on the roots of mangroves prevent the entrance of trace metals to the plant, trapping them in the soil/root interface $[8,19]$. On the contrary, if metals do reach the plant tissues there are some other factors that have to be taken in consideration in order to prevent ecological risks. Silva et al., $(1998,2006)$ [31, 32] concluded that for R.mangle the transfer of metals from canopy to sediment through leaf fall is very low in trace metal concentration and since the
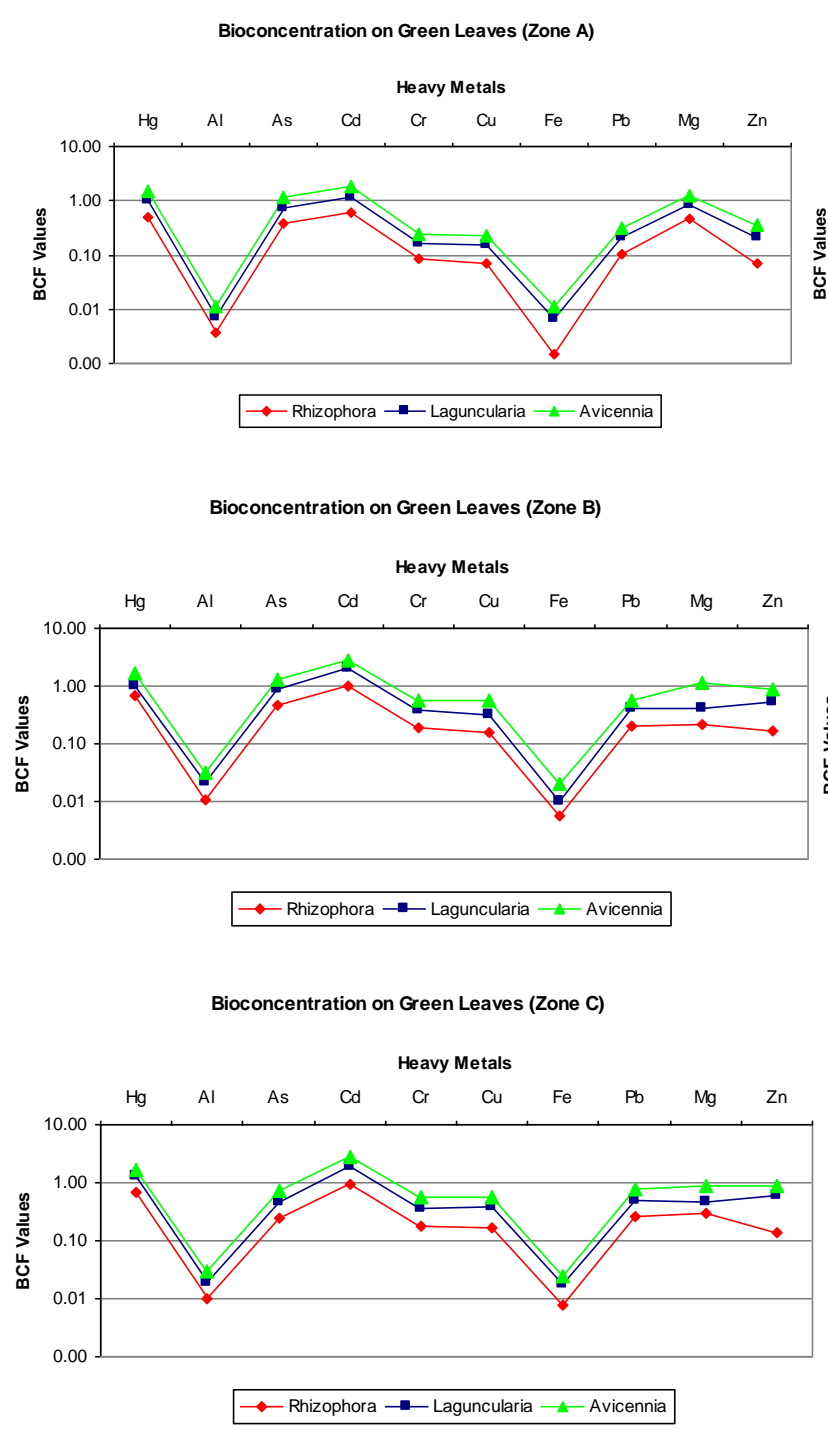

residence time of leaves on sediment is short, the export from said forest had relatively low metal concentration. Meanwhile, Wen-Jiao et al., (1997) [9] suggested that the trace metal concentration in residues on the forest floor could be 2-30 times higher than those in plants and litterfall (R.stylosa), in consequence the export of metals through detritus to adjacent ecosystems could represent a high ecological risk.
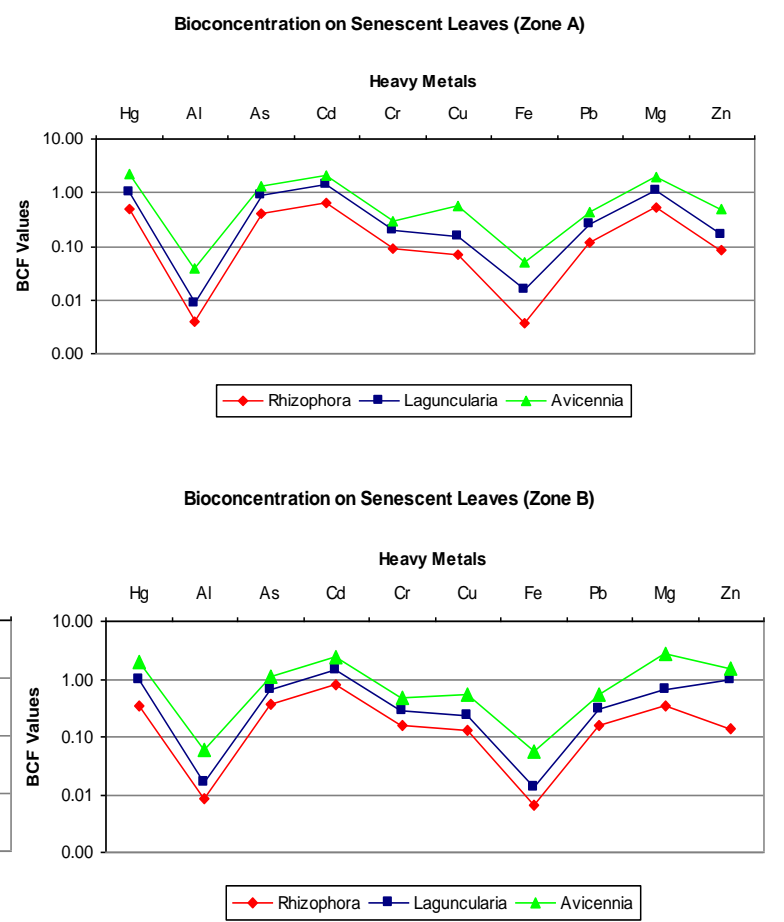

Bioconcentration on Green Leaves (Zone C)

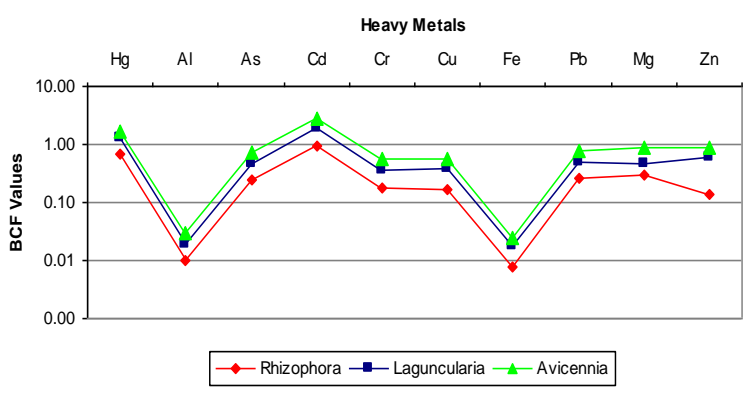

Figure 6. Comparison of bioconcentration capacity among mangrove species.

\section{Bioconcentration}

Results from BCF to a certain extent compliment $\mathrm{RT} \%$ results since having low $\mathrm{RT} \%$ values can be translated into higher bioconcentration in leaf tissue. BCF formula can be used to calculate the accumulation of contaminants in any tissue of the plant in relation with the concentration of the contaminant in soil. Since we analyzed $\mathrm{RT} \%$ in leaves we adapted BCF formula to calculate the heavy metal accumulation on both, green and senescent leaves. As expected, based on RT\% results (Figure 6), in comparison with R.mangle and L.racemosa, A.germinans showed higher BCF 
values in both leaf states. Some variations on the general pattern of heavy metals' RT\%'s and BCF's may be due to an additional source of the metal such as deposition. BCF values for senescent leaves tended to be higher than for green leaves, therefore the risk of exporting heavy metals into the environment is even higher than expected. In Puerto Rico, these mangrove species produce leaf litterfall year round. This could be a major problem because as Maisto et al., (2011) [26] stated, bioconcentration of heavy metals in mangrove senescent tissues pose potential risk of animal consumption and exportation to adjacent ecosystems.

In contrast with Miao et al (2007) [33] who studied the BCF of $\mathrm{Cd}$ and $\mathrm{Mn}$ in Kandelia candel plant tissues finding that $\mathrm{BCF}$ values in seedlings had a relative high toxicity in comparison to other tissues, our results for the same metal were lower. Rachman et al. (2011) [34] also performed studies in the same species and concluded that they have high toxicity resistance to heavy metals and accumulate them in cell-wall tissue, roots and stem. This could also be an explanation for having lower values in our mangrove species.

Table 1. ANOVA for green and senescent leaves for the three species among the three zones

\begin{tabular}{|l|c|c|c|c|}
\hline \multirow{2}{*}{$\begin{array}{l}\text { Heavy } \\
\text { Metal }\end{array}$} & \multicolumn{2}{|c|}{ Green } & \multicolumn{2}{c|}{ Senescent } \\
\hline $\mathrm{Hg}$ & 0.33 & .729 & 0.33 & .729 \\
\hline $\mathrm{Al}$ & 12.06 & $.008^{*}$ & 12.06 & $.008^{*}$ \\
\hline $\mathrm{As}$ & 11.47 & $.009^{*}$ & 11.47 & $.009^{*}$ \\
\hline $\mathrm{Cd}$ & 11.53 & $.009^{*}$ & 11.53 & $.009^{*}$ \\
\hline $\mathrm{Cr}$ & 11.47 & $.009^{*}$ & 11.47 & $.009^{*}$ \\
\hline $\mathrm{Cu}$ & 0.95 & .437 & 0.95 & .437 \\
\hline $\mathrm{Fe}$ & 0.16 & .852 & 0.16 & .852 \\
\hline $\mathrm{Pb}$ & 11.53 & $.009^{*}$ & 11.53 & $.009^{*}$ \\
\hline $\mathrm{Mg}$ & 0.36 & .714 & 0.36 & .714 \\
\hline $\mathrm{Zn}$ & 0.18 & .843 & 0.18 & .843 \\
\hline$* 5 \%$ Significance & & & \\
\hline
\end{tabular}

\section{Statistical analysis}

Although both $\mathrm{RT} \%$ and BCF formulas showed overwhelming results, when statistical analyses were applied significant differences among the three mangrove species was not found. However, statistical significance was found for some heavy metals in certain species. Table 1 shows the ANOVA for green and senescent leaves of the three species in all zones $(\mathrm{A}, \mathrm{B}, \mathrm{C})$. Results indicate that $\mathrm{Al}, \mathrm{As}, \mathrm{Cd}, \mathrm{Cr}$ and $\mathrm{Pb}$ had a statistical significance of $5 \%$ for both leaf types. For RT\% (Table 2) and BCF (Table 3) significant values were less likely to be found. In the case of $\mathrm{RT} \%, 5 \%$ significance was only found for $\mathrm{Cu}$ in R.mangle and $\mathrm{Pb}$ in A.germinans and in the same specie, $\mathrm{Al}$ to a $10 \%$.
In accordance with BCF formula results for A.germinans, $10 \%$ significance was found for $\mathrm{Hg}$ and $5 \%$ for $\mathrm{Al}$ and $\mathrm{Fe}$.

Table 2. T-test significance for retranslocation in leaves of the three species

\begin{tabular}{|l|l|l|l|}
\hline $\begin{array}{l}\text { Heavy } \\
\text { Metal }\end{array}$ & Rhizophora & Laguncularia & Avicennia \\
\hline & Sig. & Sig. & Sig. \\
\hline $\mathrm{Hg}$ & .423 & .184 & .139 \\
\hline $\mathrm{Al}$ & .307 & .825 & $.098^{*}$ \\
\hline $\mathrm{As}$ & .298 & .845 & .373 \\
\hline $\mathrm{Cd}$ & .324 & .784 & .372 \\
\hline $\mathrm{Cr}$ & .298 & .845 & .373 \\
\hline $\mathrm{Cu}$ & $.052 * *$ & .179 & .363 \\
\hline $\mathrm{Fe}$ & .326 & .475 & .106 \\
\hline $\mathrm{Pb}$ & .324 & .784 & $.051^{* *}$ \\
\hline $\mathrm{Mg}$ & .956 & .287 & .195 \\
\hline $\mathrm{Zn}$ & .604 & .843 & .188 \\
\hline$* 10 \%$ Significance & $* * 5 \%$ Significance \\
\hline
\end{tabular}

Table 3. T-test significance for bioconcentration

\begin{tabular}{|c|c|c|c|}
\hline $\begin{array}{l}\text { Heavy } \\
\text { Metal }\end{array}$ & Rhizophora & Laguncularia & Avicennia \\
\hline & Sig. & Sig. & Sig. \\
\hline $\mathrm{Hg}$ & .393 & .387 & $.087 *$ \\
\hline $\mathrm{Al}$ & .916 & .904 & $.036^{* *}$ \\
\hline As & .713 & .952 & .858 \\
\hline $\mathrm{Cd}$ & .545 & .712 & .850 \\
\hline $\mathrm{Cr}$ & .615 & .810 & .877 \\
\hline $\mathrm{Cu}$ & .643 & .455 & .281 \\
\hline $\mathrm{Fe}$ & .307 & .423 & $.004 * *$ \\
\hline $\mathrm{Pb}$ & .640 & .844 & .557 \\
\hline $\mathrm{Mg}$ & .861 & .592 & .346 \\
\hline $\mathrm{Zn}$ & .712 & .756 & .620 \\
\hline
\end{tabular}

\section{Sediments}

High metal concentrations were found in our entire research area. Concentrations for As, Se, $\mathrm{Pb}, \mathrm{Hg}, \mathrm{Cd}, \mathrm{Cu}$ and $\mathrm{Zn}$ demonstrated to be higher than the baseline adapted from Florida soils. Data indicated that the concentrations of heavy metals in sediments could be a potential risk for the life in and surrounding this ecosystem.

\section{Retranslocation/Bioconcentration in $\boldsymbol{R}$ mangle, L. racemosa and $A$. germinans.}

The concept of nutrient use efficiency or retranslocation $[16,14]$ is related with the ability of plant to withdraw elements from senescing leaves to phloem and making these nutrients available again. It has been proven that plants are more efficient in the use of N, P, K, Ca when they grow on nutrient-deficient soils. This mechanism is developed by plants for its survival, but the reason why it is happening for heavy metals, even in low ranges, is still uncertain. In order to understand how this 
process takes place biochemical analyses of heavy metal in mangroves should be assessed. In addition, taking in consideration the physicochemical characteristics of sediments would probably help to understand the bioavailability of heavy metals for mangrove uptake. However, $\mathrm{BCF}$ results complement $\mathrm{RT} \%$ suggesting that the three studied mangrove species tend to bioconcentrate heavy metals at different ranges and that is mostly in senescent leaves.

The ANOVA (Table 1) of our study showed that $\mathrm{Al}, \mathrm{As}, \mathrm{Cd}, \mathrm{Cr}$ and $\mathrm{Pb}$ had a $5 \%$ significance among the green and senescent leaves of the three mangrove species. These concentrations reflect the undeniable ability of mangroves in our area to bioaccumulate. The t-test analysis (Table 2) for retranslocation indicates that only R.mangle and A.germinans had significant values for a few heavy metals.

T-test analysis for bioconconcentration (Table 3) suggest that A.germinans is the only species to bioconcentrate significantly $\mathrm{Hg}, \mathrm{Al}$, and Fe. In general, results from our research suggest that the three mangrove species accumulate $\mathrm{Fe}, \mathrm{Mg}, \mathrm{Zn}$, which are classified, at certain concentrations, as essential trace metals for plant development [35]. Greater variety of heavy metals was seen to be bioaccumulated as the contamination rose among the zones $(\mathrm{C}<\mathrm{B}<$ A). In addition to the previous mentioned heavy metals, L.racemosa accumulates $\mathrm{Cd}$ and $\mathrm{Al}$ and A.germinans accumulates $\mathrm{Cu}, \mathrm{Al}, \mathrm{Pb}, \mathrm{Hg}$.

Among the three species, A.germinans showed to accumulate the wider variety of heavy metals. These other metals, in high concentrations are noxious to the environment and could pose a risk over thropic chains. The possible export of these heavy metals via detritus from our ecosystem must be analyzed to evaluate risk of bioaccumulation in marine organisms.

\section{CONCLUSION}

Results from our research suggest that the three mangrove species accumulate $\mathrm{Fe}, \mathrm{Mg}$, and $\mathrm{Zn}$. However, greater variety of heavy metals was seen to be bioaccumulated as the contamination rose among the zones $(\mathrm{C}<\mathrm{B}<\mathrm{A})$. Among the three species, A.germinans showed to accumulate the wider variety of heavy metals.

\section{ACKNOWLEDGEMENTS}

This research was funded by the Southeastern Research Station of the US. Forest Service. Grant \#: 11-DG-11330101-110

\section{REFERENCES}

1. San Juan Bay Estuary Program/ US Environmental Protection Agency San Juan, P.R (2000) Comprehensive Conservation and Management Plan (CCMP) for the San Juan Bay Estuary.

2. Negrón J. (2008) Evaluación de la presencia de Bifenilos PCB's en el suelo de la Ciénaga Las Cucharillas en Cataño y los riesgos potenciales a las comunidades adyadcentes. Unpublished thesis dissertation, School of Environmental Affairs, Universidad Metropolitana.

3. Sotomayor CJ (2007) Evaluación de presencia de metales pesados en la ciénaga Las Cucharillas. Unpublished thesis dissertation, School of Environmental Affairs, Universidad Metropolitana.

4. Miller GL \& AE Lugo (2009) Guide to the ecological systems of Puerto Rico. Gen. Tech. Rep. IITF-GTR-35, Chapter 5

5. Valiela I, JL Bowen \& JA Cork (2011) Mangrove forests: one of the world's threatened major tropical environments. Bioscience. 51(10)

6. Defew LH, JM Mair \& HM Guzman (2005) An assessment of metal contamination in mangrove sediments and leaves from Punta Mala Bay, Pacific Panama. Marine Pollution Bulletin. 50:547-552

7. Lacerda LD, CE Carvalho, KF Tanizaki, AR Ovaile \& CE Rezende (1993) The biogeochemistry and trace metal distribution of mangrove rhizospheres. Biotropica. 25(3):252257

8. Machado W, KF Tanizaki \& LD Lacerda (2004) Metal accumulation on the fine roots of Rhizophora mangle L. ISME/GLOMIS Electronic Journal. 4(1)

9. Wen-jiao Z, C Xiao-yong, L Peng (1997) Accumulation and biological cycling of heavy metal elements in Rhizophora stylosa mangroves in Yingluo Bay, China. Marine Ecology Progress Series. 159:293-301

10. Pandey BB \& MH Fulekar (2012) Bioremediation technology: A new horizon for environmental clean-up. Biology and Medicine. 4(1):51-59.

11. Hammad, DM (2011) Cu, Ni and $\mathrm{Zn}$ phytoremediation and translocation by water hyacinth plant at different aquatic environments. Australian Journal of Basic and Applied Sciences 2011. 5(11):11-22.

12. Mellem J, H Baijnath \& B Odhaw (2009) Translocation and accumulation of $\mathrm{Cr}, \mathrm{Hg}$, $\mathrm{As}$, $\mathrm{Pb}, \mathrm{Cu}$ and $\mathrm{Ni}$ by Amarranthus dubius (Amaranthaceae) from contaminated sites. Journal of Environmental Science and Health. Part A 44:568-575

13. Lugo AE (1998) Mangrove Forests: A Though System to Invade but an Easy One to Rehabilitate. Marine Pollution Bulletin. 37: 427430 
14. Vitousek PM (1982) Nutrient cycling and nutrient use efficiency. American Naturalist. 119:553-572

15. Vitousek PM (1984) Litterfall, Nutrient Cycling and Nutrient Limitation in Tropical Forest. Ecol. 65(1):285-298

16. Allison SD \& PM Vitousek (2004) Rapid nutrient cycling in leaf litter from invasive plants in Hawai'i. Oecologia. 141(4):612-619 doi:10. $1007 / \mathrm{s} 00442-004-16.79-z$

17. Aerts R (1996) Nutrients resorption from senescing leaves of perennials: Are there general patterns? Journal of Ecology. 84(4):597-608

18. Lacerda LD, CE Rezende, DM Villella \& MC Fernandes (1986) Metallic composition of mangrove leaves from the southeastern Brazilian coast. Rev. Brasil Biol. 46(2):395-399

19. Machado W, EV Silva-Filho, RR Oliveira \& LD Lacerda (2002) Trace metal retention in mangrove ecosystems in Guanabara Bay, SE Brazil. Marine Pollution Bulletin. 44:1277-12

20. Machado W, B Gueiros, S Lisboa \& L Lacerda (2005) Trace metals in mangrove seedlings: role of iron plaque formation. Wetlands Ecology and Management. 13(2)

21. Jingchun L, Y Chongling, MR Macnair, H Jun \& L Yuhong (2006) Distribution and speciation of some metals in mangrove sediments from Jiulong river stuary, People Republic of China. Bulletin of Environmental Contamination and Toxicology. 76:815-822.

22. Environmental Protection Agency EPA sediment sampling methods SOP\# 2016. [http://www.epa. gov/region6/qa/qadevtools/mod5_sops/sedime nt_sampling/ertsop2016-sediment.pdf ]

23. Environmental Protection Agency Standardized Analytical Methods for Environmental Restoration Following Homeland Security Events. [http://www.epa.gov/sam/SAM_2012_ 07162012.pdf ]

24. Chen M, LQ Ma \& WG Harris (1999) Baseline Concentrations of 15 trace elements in Florida surface soils. Journal of Environmental Quality. 28(4):1173-1181.

25. Kabata-Pendias A, S Dudka \& A Chlopecha (1992) Background levels and environmental influences on trace metals in soils of the temperate humid zone of Europe. Biochemistry of Trace metals. CRC Press, Boca Raton, FL: 6184.

26. Maisto G, S Manzo, F De Nicola, R Carotenudo, A Rocco \& A Alfani (2011) Assessment of the effects of $\mathrm{Cr}, \mathrm{Cu}, \mathrm{Ni}$ and $\mathrm{Pb}$ soil contamination by Eco-monitoring. doi: 10.1039/c1 em 1049a

27. Seguinot-Barbosa J (2002) Concentración de metales en el área manglar de Mar Negro, Reserva Nacional de Investigación Estuarina (Guayama-Salinas), Puerto Rico. Departamento de Salud Ambiental, Escuela Graduada de Salud Pública, Recinto de Ciencias Médicas.

28. Wang WQ, M Wang \& P Lin (2003) Seasonal changes in element contents in mangrove element retranslocation during leave senescence. Plant and Soil. 252:187-193

29. Musa JC (1986) Influencia de los tributarios de agua dulce en las características físico-químicas de los suelos, productividad, eficiencias y uso de nutrientes en el mangle de Rhizophora mangle en Laguna Joyuda, Puerto Rico. Ph.D. Thesis. Universidad de Puerto Rico, Mayaguez.

30. Mac Farlane G (2002) Leaf biochemical parameters in Avicennia marina as potential biomarkers of heavy metal stress in estuarine ecosystems. Marine Pollution Bulletin. 44(3): 244-256

31. Silva C, L Lacerda, A Ovalle \& C Rezende (1998) The dynamics of heavy metals through litterfall and decomposition in a Red mangrove forest. Mangrove and Salt Marshes. 2(3):149-157

32. Silva C, A Silva \& S Oliveira (2006) Concentration stock and transport rate of heavy metals in a tropical Red Mangrove, Natal, Brazil. Marine Chemistry. 99(1-4):2-11

33. Miao S, G Chen, R De Laune \& A Jugsujinda (2007) Partitioning and removal of $\mathrm{Cd}$ and $\mathrm{Mn}$ using a simulated mangrove wastewater treatment system. Journal of Environmental Science and Health. 42(4):405-411

34. Rahman M, Y Chongling \& K Islam (2011) Accumulation, distributuion and toxicological effects induced by Cadmium on the development of mangrove plant Kandelia Candel (L). Contemporary Problems of Ecology. 4(2):133139

Ray M (1999) Essential plant nutrients: Their presence in North Carolina soils and role in plant nutrient. North Carolina Department of Agriculture and Consumer Services. [http:// www.ncagr.gov/agronomi/pdffiles/essnutr. pdf] 